\title{
A Bibliometric and Visualization Analysis of Socially Responsible Funds
}

\author{
Laura Fabregat-Aibar *(-), M. Glòria Barberà-Mariné ${ }^{\circledR}$, Antonio Terceño and Laia Pié \\ Department of Business Management, Faculty of Business and Economics, Universitat Rovira i Virgili, \\ 43204 Reus, Spain; gloria.barbera@urv.cat (M.G.B.-M.); antonio.terceno@urv.cat (A.T.); laia.pie@urv.cat (L.P.) \\ * Correspondence: laura.fabregat@urv.cat
}

Received: 25 March 2019; Accepted: 29 April 2019; Published: 1 May 2019

\begin{abstract}
The aims of this paper are (i) to identify which documents are the most influential when analyzing socially responsible funds, and (ii) to identify the conceptual structure of the field of research through co-word analysis. To achieve the proposed objectives, the VOS Viewer and two databases, Web of Science (WOS) and Scopus, were used for the period 1988-2018, and a total of 209 research papers were analyzed. This analysis provides an insight into the nature and trends of research on socially responsible investment (SRI) funds.
\end{abstract}

Keywords: bibliometric analysis; VOS Viewer; Socially Responsible Funds; Socially Responsible Investment (SRI); green funds; co-citation analysis

\section{Introduction}

The 2008 subprime crisis and increased social awareness have led to a growing interest in topics related to socially responsible investment (SRI). SRI is a long-term investment that integrates environmental, social and corporate governance criteria (ESG). According to the Global Sustainable Investment Alliance (GSIA), SRI reached 24 trillion euros in 2016, registering a growth of $25.2 \%$ between 2014 and 2016. So, green and sustainable finance is more important nowadays than ever before [1].

This increased social interest coincides with international initiatives aimed at developing environmental and social policies on sustainable finance issues, such as the Action Plan on sustainable finance adopted by the European Commission in March 2018. This plan has three main objectives: (i) To redirect capital flows towards sustainable investment to achieve sustainable and inclusive growth, (ii) to manage financial risks stemming from climate change, environmental degradation and social issues, and (iii) to foster transparency and long-termism in financial and economic activity. Therefore, the main purpose is to enhance the role of finance and to build an economy that enables the goals of the Paris Agreement (2015) and the EU for sustainable development to be reached.

The EU is strongly supporting the transition to a low-carbon, more resource-efficient, and sustainable economy and it wants to build a financial system that supports sustainable growth.

In a global sense, mutual funds are one of the most important instruments for investing savings. At the end of 2017, the total net assets of funds worldwide was 41.1 trillion euros, a significant growth compared to 2008 when total net assets recorded 14.7 trillion euros. Furthermore, according to the IMF, the volume of assets of mutual funds and pension funds involve $102.3 \%$ of world gross domestic product (GDP).

A socially responsible fund is one that takes not only financial considerations into account when selecting its investments, but it also integrates environmental, social and governance criteria in the selection of stocks. Environmental criteria refer to any aspect of the company activity that positively or negatively affects the environment (greenhouse gas emissions, renewable energies, energetic efficiency, among others). Social criteria include aspects related to society in general (employment regulations, 
health regulations, etc.). Good governance refers to management quality, culture, the company risk profile, and so on.

Some positive and negative screens are applied to specify the social and environmental impact of investments. Renneboog et al. [2] presents a summary of the SRI screens used by SRI funds around the world. The negative screens exclude companies, economic sectors, products, and even countries from their investments for bad social, environmental, ethical or corporate governance practices (alcohol, tobacco, gambling and defense industries, among others). SRI portfolios based on positive screens select companies with good practices in these aspects. According to the European Sustainable Investment Forum (EUROSIF) 2016 report, exclusions are still the most popular SRI approach in European countries.

This paper aims (i) to identify which documents are the most influential when analyzing socially responsible funds, and (ii) to determine the intellectual structure of the field through co-citation analysis.

To achieve the proposed objectives, the VOS Viewer software, developed by Van Eck and Waltman [3], is used. The main advantage of this software is the easy visualization of the co-citation network.

In the field of management, there are some bibliometric studies that use science mapping for topics related to business organization [4,5], tourism [6-8], sustainability [9,10], supply chain management [11,12], and social media [13], among others. Moreover, there are other bibliometric studies, which analyze the production of a single journal to provide an overview of the main trends in it $[14,15]$.

Bibliometric mapping approach is a way to visualize the state of art of a research area to know what options the researcher has to widen their lines of research and to initiate new focuses in a research field $[16,17]$. No paper has applied this methodology in the field of socially responsible funds.

The results of this paper are especially relevant considering the increasing emphasis from the European Commission to establish the standards and labels for sustainable financial products, the Action Plan on Sustainable Finance, and the Paris Agreement on Climate Change. This study will provide academics and practitioners with a broad view of the interest in SRI funds and will identify new approaches or hot topics related to it. Furthermore, it will inform them about which authors and papers are the most influential and the trend of different issues related to socially responsible funds. This paper expected to contribute to the way to understanding the SRI funds, providing useful insights to academics who want to study this field.

This paper is organized as follows. Section 2 is a review of different bibliometric methods. Section 3 details the methodology carried out in this study, Section 4 shows the trend in publications about socially responsible funds and, in Section 5, the main results are detailed. Finally, in the last section, the conclusions, implications and limitations are presented.

\section{Bibliometric Methods}

According to Corsini et al. [17], there are several reasons to adopt bibliometric methods: (i) You can obtain an overview of the scientific literature, (ii) traditional reviews provide a critical and subjective summarization of selected scientific papers and, (iii) nowadays studies with data have more relevance than those subjective analyses.

In general, bibliometric studies can be categorized into three groups: Review techniques, evaluative techniques, and relational techniques $[18,19]$.

Review techniques include traditional review methods such as systematic literature reviews, meta-analyses and qualitative studies. These kinds of techniques generate knowledge by using the bibliographic data of published documents and statistical analyses.

Evaluative techniques measure the academic impact and are classified into three groups [20]. The first group includes measures of productivity such as the number of papers, both per year and per individual author. The second group comprises impact metrics such as the total number of citations, both per year and per individual author/journal, among others. Finally, the third group consists of 
hybrid metrics, such as the average number of citations per paper, as well as indices that consider productivity and impact, for example, the $\mathrm{H}$ index [21] and its variants. These techniques inform about the relative influence of the documents but do not allow identification of networks between authors, publications or journals [22].

Relational techniques explore the relationship between units of analysis within a research field. These types of studies inform about the structure of a research topic, identify patterns among authors or affiliations, and detect hot topics and research methods. These techniques can be divided into four types of analyses: Co-citation analysis, bibliographic coupling, co-authorship analysis, and co-word analysis [22].

Small [23] proposes co-citation analysis to detect the intellectual structure of a research topic. Co-citation is given when two items are cited together by a third paper. This analysis considers that two papers cited together have thematic similarity, and a higher frequency of co-citation implies a greater affinity between them. Small [23] applies co-citation analysis to documents, but this analysis can also be extended using other units of analysis, such as authors or journals. Author co-citation aims to detect which authors are most frequently cited together [24], while journal co-citation analysis shows which sources are cited most frequently [25]. Some studies that apply the co-citation analysis are Köseaglu et al. [7], Leung et al. [13], Appio et al. [16] and Ferreira [26].

Another technique is bibliographic coupling which, unlike the previous method, uses the number of references shared by two documents as a measure of similarity [22]. In other words, a greater overlap between the references of two papers implies a greater connection between them. For example, Ferreira [26] and Andrade-Valbuena and Merigó [27] applied this analysis.

Co-authorship analysis studies the social structure of a research field [28]. Since bibliographic data contain information about the authors' institutional affiliations and their geographical location, co-authorship analysis can be carried out at the institutions and countries level. Some examples of this application are Koseoglu et al. [19] and Liao et al. [29].

Co-word analysis is a content analysis using the author keywords to study the conceptual structure in a research field [30]. This analysis is the only method that uses the content of the documents to construct a measure of similarity, while the other techniques connect documents indirectly through citations or co-authorship. This technique is used in studies such as Leung et al. [13], Benavides-Velasco et al. [31], and Mora-Valentín et al. [32] and is one of the most effective methods for the development of trends and emerging topics in a scientific field.

In the field of management, Zupic and Cater [22] proposed recommended workflow guidelines for mapping scientific research with bibliometric methods: (1) Research design, (2) compilation of bibliometric data, (3) analysis, (4) visualization, and (5) interpretation.

This research design defines the research question(s) and chooses the appropriate bibliometric method. In this paper, the research questions are the following: (1) Which documents are the most influential in socially responsible funds? And (2) what is the intellectual structure of the research field and how does it evolve? Therefore, first, we realize a citation analysis to discover the most influential documents in the field and, second, we choose the co-citation analysis to identify the intellectual structure

\section{Data Collection}

The compilation of bibliometric data includes the selection of the database(s), to filter the bibliographic data and to refine it. The software must then be chosen and a decision taken as to how to visualize the information.

We decide to use two databases: Scopus and the Web of Science (WOS) Core Collection. The WOS database is the most frequently used database for bibliometric studies in management and organization $[4,5,13]$. However, Scopus is a broader database compared to WOS, and this more extensive coverage is useful for mapping smaller research fields that are insufficiently covered by the former [22]. 
To select the publications to include in our analysis, we needed to define the steps to synthesize the information. Figure 1 graphically represents the steps in the review process using the PRISMA methodology [33].

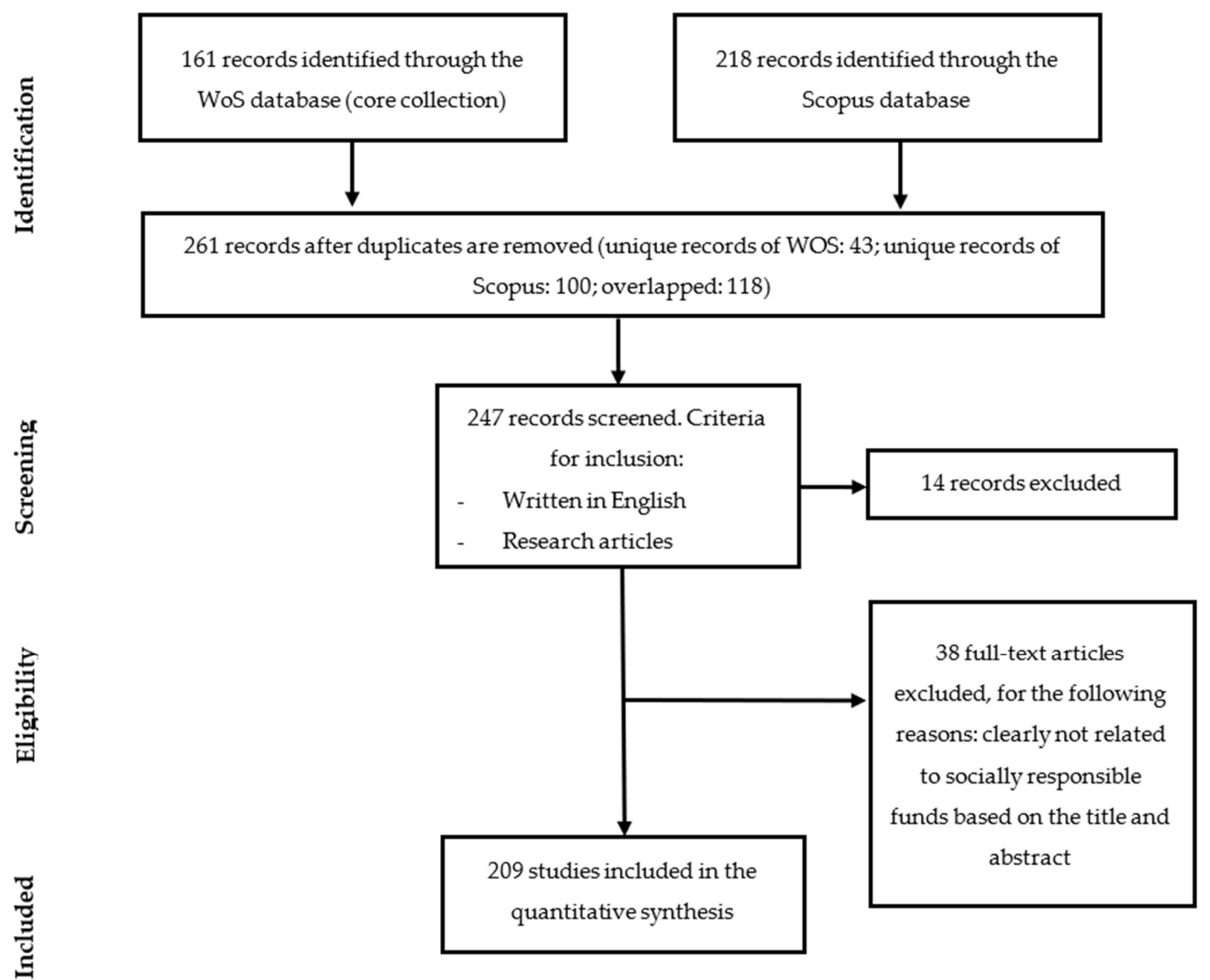

Figure 1. Steps to systematize the information (PRISMA). Adapted from Reference [33].

In the identification phase, the first step was to choose the keywords used to achieve our objectives in this paper. The keywords have been identified from the core references of the field [2,34-37] and these keywords can appear in the title, author keywords or abstract. The search was not restricted to a specific start date and the month of July 2018 was established as the final date.

The exact string used to search the papers was the following:

(("green funds") OR ("ethical funds") OR (("mutual funds") AND ("socially responsible invest" OR ("socially respons") OR ("ethical invest*") OR ("SRI"))).

In this phase, 161 documents were found in WOS and 218 in Scopus. Many of them appear in both databases, so once the duplicates have been eliminated the total number of documents was 261 .

In the screening phase, we decided to include all the documents in English and research papers. We decided to exclude the grey literature (working papers and reports). So, the included categories were the following: Articles, book chapters, conference papers, conference reviews, and reviews. After applying the previously selected criteria, 14 items were excluded, leaving a total of 247 eligible papers.

In the next step (eligibility phase), after screening their titles and abstracts, 38 papers were removed because they were not directly related to socially responsible funds.

The final sample consisted of 209 documents (included phase). These documents are classified according to their main topic, although some of them contemplate more than one topic (Table 1). 
Table 1. Definitions of topics.

\begin{tabular}{llc}
\hline \multicolumn{1}{c}{ Topic } & \multicolumn{1}{c}{ Definition } & TP \\
\hline Comparative analysis & $\begin{array}{l}\text { Studies about the differences between conventional funds and SRI funds. } \\
\text { Studies related to the development about any aspect of the theoretical } \\
\text { framework of SRI funds. }\end{array}$ & 56 \\
Conceptual & $\begin{array}{l}\text { Papers focused on the corporate social responsibility in firms. } \\
\text { Management }\end{array}$ & 11 \\
Green finance & consciousness or an environmental responsibility invest in. & 12 \\
Impact crisis & Any related to the analysis about the impact of subprime mortgage crisis. & 9 \\
Investment screening & Any study related to the analysis of investment screens (positive or & 15 \\
Investor attributes & negative) in SRI funds. & 17 \\
Literature review & Studies about the investor behavior regarding ethical investments. & 19 \\
Managerial abilities & Reviews of literature on SRI funds or SRI. & 8 \\
Performance & Any study related to the analysis about which characteristics have the fund & 14 \\
Policy issues & managers to decide to invest in ethical investment. & 6 \\
Portfolio selection & Studies related to the analysis of performance in SRI funds. & 6 \\
Rating/Indicators & Studies of policies issues related to SRI funds. & 8 \\
Regulatory & Any study that proposes methodologies or techniques to select stocks in an & 12 \\
Social issues & investment portfolio. & New measures to assess the sustainability in ethical investments. \\
Others & Studies that focus on law aspects of SRI funds. & 12 \\
\hline
\end{tabular}

Abbreviations: TP $=$ Total publications.

Before analyzing the results by means of VOS Viewer, all the inconsistencies in the bibliographic data were standardized and corrected. These inconsistencies appeared due to errors in the process of capturing the WOS and Scopus data, abbreviations and mistakes made by the authors in the references. The following data was standardized: (1) The names of authors and journals, and (2) references.

To determine the singularity of the two databases, the relative index of singularity or Meyer's index, which allows for comparing the coverage of a given topic by different databases, was calculated [38]. The greater the value of the Meyer's index, the more unique is the database.

The Meyer's index was calculated as follows:

$$
\begin{aligned}
\text { Meyer Index } & =\frac{\sum \text { articles } \times \text { weight }}{\text { Total articles }} \\
\text { Scopus Meyer Index } & =\frac{100+(118 \times 0.5)}{261}=0.609 \\
\text { WOS Meyer Index } & =\frac{43+(118 \times 0.5)}{261}=0.3908
\end{aligned}
$$

The results showed a higher singularity of Scopus with $60.9 \%$ of unique articles, while $39.1 \%$ of WOS records were unique.

To measure the percentage of coverage of one database in relation to the other, the Relative Overlap was used. The overlap of the databases was calculated as follows:

$$
\begin{gathered}
\% \text { Overlap Scopus }=100 \times \frac{\mid \text { Scopus } \cap \text { WOS } \mid}{\mid \text { Scopus } \mid}=100 \times \frac{118}{218}=54.1 \% \\
\% \text { Overlap WOS }=100 \times \frac{\mid \text { Scopus } \cap \text { WOS } \mid}{\mid \text { WOS } \mid}=100 \times \frac{118}{161}=73.3 \%
\end{gathered}
$$

The results indicated that Scopus had a greater extension with $73.3 \%$ of the WOS records covered by Scopus, which justified the use of both databases. 


\section{Initial Data}

The first paper indexed about socially responsible funds examines these mutual funds from the standpoint of their investment policies, criteria for investments, information sources and resulting portfolios [39].

Figure 2 shows the trend in publications about socially responsible funds for the period 1988 to July 2018. Three distinct periods can be observed: 1988-2004, 2005-2010 and 2011 to the present. There was little academic interest in the research field in the first period, with an average of two publications per year. These papers mainly explain the concept of socially responsible investment and their studies focus on the U.S. market. In the second period, the topic begins to take on more relevance with an average of 7-8 papers per year and the main interest was analyzing if there were any significant differences between the performance of social and conventional funds applied mainly in the U.S. market or in other markets, such as the European one. Since 2010, interest in issues related to sustainability and social responsibility has increased due to the economic-financial-social context. During the period 2011-2018, the topics focused on managerial abilities and stakeholder/investor reaction, and the relationship between performance-sustainability during the period of crisis/stress and the concept of green funds began to appear in the economic literature. In 2014, a total of 28 documents related to socially responsible funds were published.

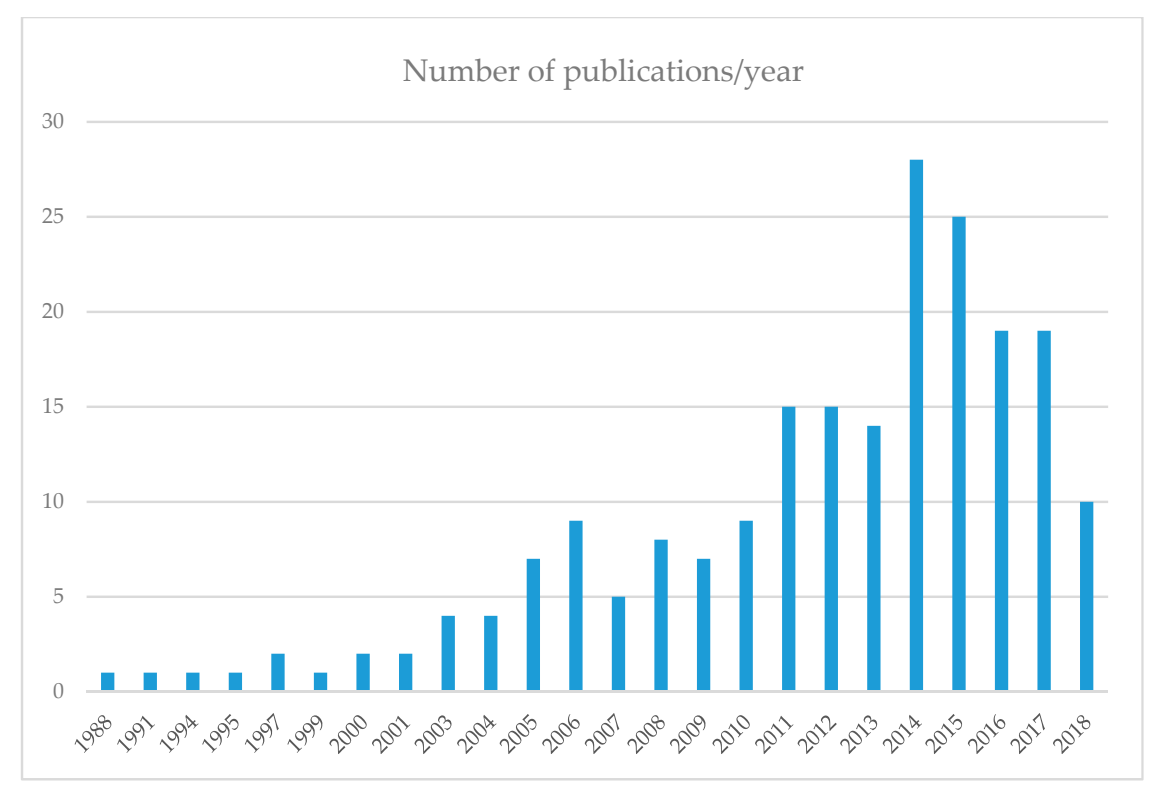

Figure 2. The annual publication on socially responsible investment (SRI) funds in the Web of Science (WOS) and Scopus databases.

Table 2 classifies the 209 publications according to the type of document. Here, $84 \%$ of the publications are shown to belong to articles, followed by book chapters (6\%), reviews (5\%), conference papers $(4 \%)$ and conference reviews (1\%).

Table 2. Number of publications according to the document type.

\begin{tabular}{ccc}
\hline Document Type & TP & $\%$ \\
\hline Article & 176 & $84.2 \%$ \\
Book chapter & 13 & $6.2 \%$ \\
Conference Paper & 9 & $4.3 \%$ \\
Conference Review & 1 & $0.5 \%$ \\
Review & 10 & $4.8 \%$ \\
\hline
\end{tabular}

Abbreviations: $\mathrm{TP}=$ total publications 


\section{Results}

\subsection{Citation Analysis}

Citation analyses identify the most cited, and, therefore, the most prominent documents in a field of research. If a paper is highly cited, it is considered to have a more significant influence on a specific topic than do other less cited papers [40].

The most cited papers are shown in Table 3. The included papers have the highest number of citations in absolute terms, ordered by the ratio $\mathrm{C} / \mathrm{Y}$ (citations per year) so as not to prioritize the year of publication.

Of the 20 most cited papers, there are two documents that carried out a review of the literature: Fowler and Hope [41] and Renneboog et al. [2]. Fowler and Hope [41], "A critical review of sustainable business indices and their impact", explores the performance of sustainable mutual funds and indices, and also examines the methodologies employed in compiling the main sustainable indices. Renneboog et al. [2] is a critical review of the literature on socially responsible investment (SRI) entitled "Socially responsible investment: institutional aspects, performance, and investor behavior", which provided an overview of the state of the literature on SRI with a total of 34.78 citations per year, and as such is the most influential paper.

Another influential paper is Barnett and Salomon [34] with 30.18 citations per year, which studied the relationship between financial and social performance for the U.S market to determine if a greater social restriction on investments led to funds performing better. A similar analysis is developed by Capelle-Blancard and Monjon [42] for the French market.

Of the 20 most influential papers, the vast majority analyzed the relation between performance and sustainability and the main difference was the sample used. One of the most influential papers is Bauer et al. [35], which compared the risk-adjusted returns of SRI funds and conventional funds in three countries: Germany, the UK and the U.S. This relation has also been analyzed in other studies:

- Statman [36] for the U.S. market, which was a comparison of the performance of different market indexes such as the S\&P500 and the Domini Social Index (DSI);

- Kreander et al. [43] for a sample of European funds (Belgium, Germany, Netherlands, Norway, Sweden and the UK);

- $\quad$ Bello [44] for U.S. funds;

- Bauer et al. [45] for Canadian funds;

- Renneboog et al. [37] in three regions: Europe, North America and Asia-Pacific;

- Cortez et al. [46] in seven European countries (the UK, Austria, Belgium, France, Germany, Netherlands and Italy);

- Abdelsalam et al. [47] for the Islamic market and Nofsinger;

- Varma [48] for the U.S. market specifically during periods of economic crisis/stress.

In recent years, the study approach changed. Renneboog et al. [49] studied the money flow into and out of socially responsible funds. Hong and Kostovetsky [50], with 15.8 citations per year, is the fifth most influential paper, which analyzed how political values influence the investment decisions of mutual fund managers. This study focused on the U.S. market and assumed that democratic and republican managers could differ in their opinions about socially responsible stocks. Utz et al. [51], with a ratio of 10.33 citations/year, analyzed whether the term socially responsible is a sales argument or if managers take social responsibility into account in all their investment decisions. Finally, Ballestero et al. [52], Bilbao-Terol et al. [53], and Bilbao et al. [54] applied a new framework to value and select portfolios, which combined socially responsible assets and conventional ones. 
Table 3. The 20 most cited papers by year.

\begin{tabular}{|c|c|c|c|c|c|c|}
\hline $\mathbf{R}$ & Ref & Authors & Title & Year & TC & $\mathrm{C} / \mathrm{Y}$ \\
\hline 1 & {$[2]$} & $\begin{array}{l}\text { Renneboog L., Ter Horst J., } \\
\text { Zhang C. }\end{array}$ & $\begin{array}{l}\text { Socially responsible investments: Institutional } \\
\text { aspects, performance, and investor behavior } \\
\text { Beyond dichotomy: The curvilinear }\end{array}$ & 2008 & 313 & 34.78 \\
\hline 2 & [34] & Barnett M.L., Salomon R.M. & $\begin{array}{l}\text { relationship between social responsibility and } \\
\text { financial performance }\end{array}$ & 2006 & 332 & 30.18 \\
\hline 3 & [35] & Bauer R., Koedijk K., Otten R. & $\begin{array}{l}\text { International evidence on ethical mutual fund } \\
\text { performance and investment style }\end{array}$ & 2005 & 314 & 26.17 \\
\hline 4 & [37] & $\begin{array}{l}\text { Renneboog L., Ter Horst J., } \\
\text { Zhang C. }\end{array}$ & $\begin{array}{l}\text { The price of ethics and stakeholder } \\
\text { governance: The performance of socially } \\
\text { responsible mutual funds }\end{array}$ & 2008 & 164 & 18.22 \\
\hline 5 & [50] & Hong H., Kostovetsky L. & Red and blue investing: Values and finance & 2012 & 79 & 15.8 \\
\hline 6 & [36] & Statman M. & Socially Responsible Mutual Funds & 2000 & 263 & 15.47 \\
\hline 7 & [55] & Bollen N.P.B. & Mutual fund attributes and investor behavior & 2007 & 124 & 12.4 \\
\hline 8 & [48] & Nofsinger J., Varma A. & Socially responsible funds and market crises & 2014 & 36 & 12 \\
\hline 9 & [54] & $\begin{array}{l}\text { Bilbao-Terol A., Arenas-Parra } \\
\text { M., Cañal-Fernández V., } \\
\text { Antomil-Ibias, J. }\end{array}$ & $\begin{array}{l}\text { Using TOPSIS for assessing the sustainability } \\
\text { of government bond funds }\end{array}$ & 2014 & 35 & 11.67 \\
\hline 10 & [45] & Bauer R., Derwall J., Otten R. & $\begin{array}{l}\text { The ethical mutual fund performance debate: } \\
\text { New evidence from Canada }\end{array}$ & 2007 & 115 & 11.5 \\
\hline 11 & [43] & $\begin{array}{l}\text { Kreander N., Gray R.H., } \\
\text { Power D.M., Sinclair C.D. }\end{array}$ & $\begin{array}{l}\text { Evaluating the performance of ethical and } \\
\text { non-ethical funds: A matched pair analysis }\end{array}$ & 2005 & 124 & 10.33 \\
\hline 12 & [51] & $\begin{array}{l}\text { Utz S., Wimmer M., } \\
\text { Hirschberger M., Steuer R.E. }\end{array}$ & $\begin{array}{l}\text { Tri-criterion inverse portfolio optimization } \\
\text { with application to socially responsible } \\
\text { mutual funds }\end{array}$ & 2014 & 31 & 10.33 \\
\hline 13 & [42] & Capelle-Blancard G., Monjon S. & $\begin{array}{l}\text { The Performance of Socially Responsible } \\
\text { Funds: Does the Screening Process Matter? }\end{array}$ & 2014 & 30 & 10 \\
\hline 14 & [49] & $\begin{array}{l}\text { Renneboog L., Ter Horst J., } \\
\text { Zhang C. }\end{array}$ & $\begin{array}{l}\text { Is ethical money financially smart? } \\
\text { Nonfinancial attributes and money flows of } \\
\text { socially responsible investment funds }\end{array}$ & 2011 & 57 & 9.5 \\
\hline 15 & [44] & Bello Z.Y. & $\begin{array}{l}\text { Socially responsible investing and } \\
\text { portfolio diversification }\end{array}$ & 2005 & 109 & 9.083 \\
\hline 16 & [52] & $\begin{array}{l}\text { Ballestero E., Bravo M., } \\
\text { Perez-Gladish B., } \\
\text { Arenas-Parra M., } \\
\text { Plà-Santamaria D. }\end{array}$ & $\begin{array}{l}\text { Socially Responsible Investment: } \\
\text { A multicriteria approach to portfolio selection } \\
\text { combining ethical and financial objectives }\end{array}$ & 2012 & 44 & 8.8 \\
\hline 17 & [47] & $\begin{array}{l}\text { Abdelsalam O., Fethi M.D., } \\
\text { Matallín-Sáez J.C., } \\
\text { Tortosa-Ausina E. }\end{array}$ & $\begin{array}{l}\text { On the comparative performance of socially } \\
\text { responsible and Islamic mutual funds }\end{array}$ & 2014 & 26 & 8.667 \\
\hline 18 & [41] & Fowler S.J., Hope C. & $\begin{array}{l}\text { A critical review of sustainable business } \\
\text { indices and their impact }\end{array}$ & 2007 & 80 & 8 \\
\hline 19 & [53] & $\begin{array}{l}\text { Bilbao-Terol A., } \\
\text { Arenas-Parra M., } \\
\text { Cañal-Fernández V. }\end{array}$ & $\begin{array}{l}\text { Selection of socially responsible portfolios } \\
\text { using goal programming and fuzzy } \\
\text { technology }\end{array}$ & 2012 & 40 & 8 \\
\hline 20 & [46] & Cortez, M., Silva, F., Areal, N. & $\begin{array}{l}\text { The performance of European socially } \\
\text { responsible funds }\end{array}$ & 2009 & 61 & 7.63 \\
\hline
\end{tabular}

Abbreviations: $\mathrm{R}=$ rank; Ref = number of reference; $\mathrm{TC}=$ Total citations; $\mathrm{C} / \mathrm{Y}$ : Citations per year.

\subsection{Co-Citation Analysis}

Different types of co-citations can be used based on the unit of analysis: Document co-citation analysis, author co-citation analysis, and journal co-citation analysis.

\subsubsection{Document Co-Citation Analysis}

The first co-citation study analyzed the document co-citation network on socially responsible funds. Small [23] assumes that frequently cited papers represent the key concepts, methods or experiments in a field. So, this analysis will allow us to know which documents define the intellectual structure in issues of sustainability and mutual funds.

In the 209 documents analyzed, there were a total of 3242 cited papers, of which 70 met the threshold of a minimum of 10 citations per paper (Figure 3). Each node represented a single reference and its size indicated the number of citations per document. The link represented a co-citation. The 
number of identical citing items defined the strength of co-citation between the two cited papers. So, co-citation was the frequency with which two papers from earlier literature were cited together, by the later literature [23].

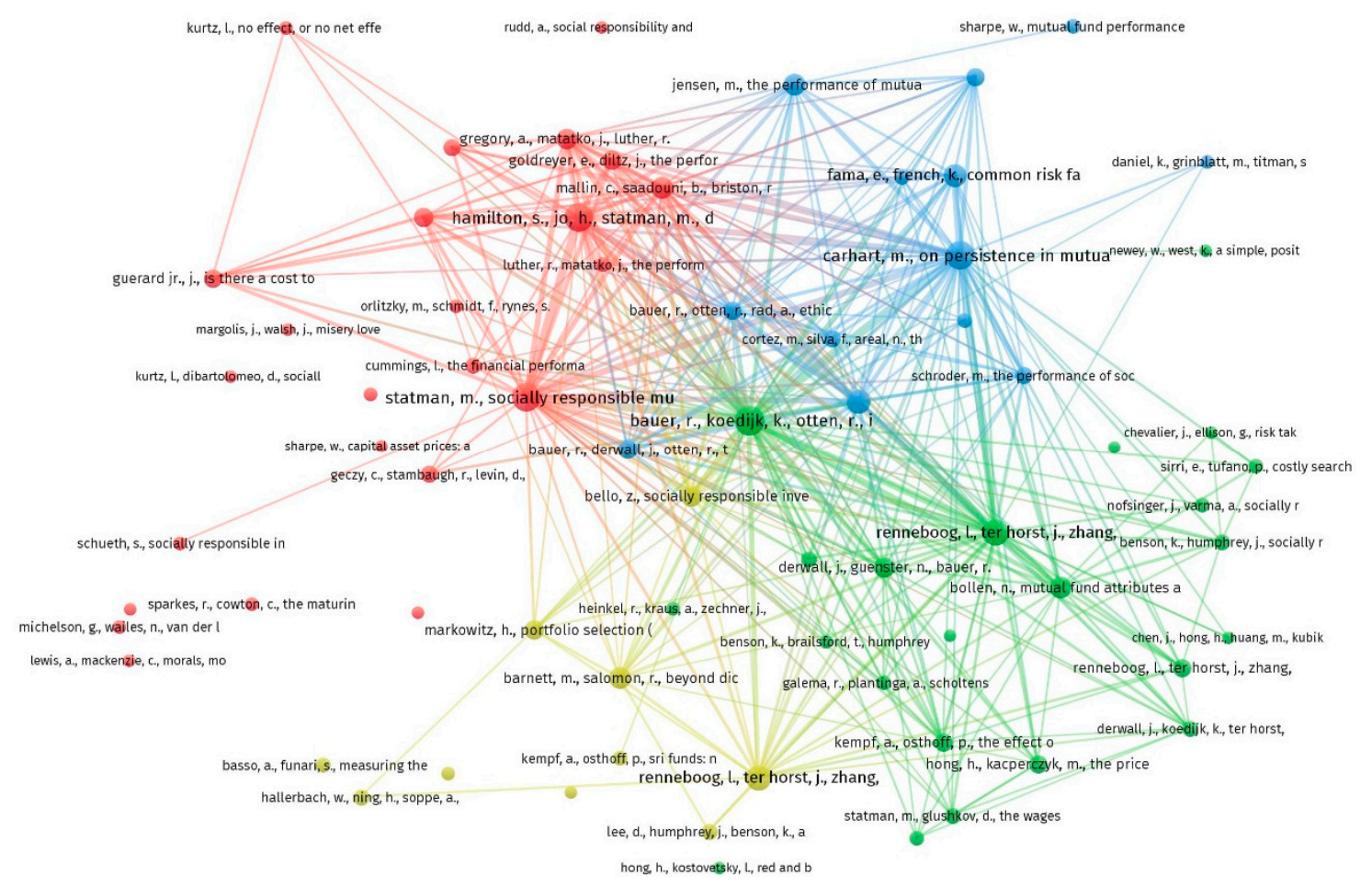

Figure 3. Co-citation network of documents of socially responsible funds

The nodes with the same color belonged to the same cluster. The association strength normalization method used by the VOS Viewer software [3] identified four groups.

The red cluster represented the influential papers on SRI funds during the 1990s and was the most cited cluster (478 citations). In general, the major question of these studies was whether the SRI funds performed better or worse than conventional funds and the main data analyzed was the U.S. and UK mutual funds. As for the U.S. market, the following documents stood out: Hamilton et al. [56], Sauer [57], Goldreyer and Diltz [58], and Statman [36]. And for the UK market, Luther et al. [59], Mallin et al. [60] and Gregory et al. [61] had a stronger link strength.

On the other hand, the green cluster was the most important in terms of total link strength (6592) and represented the recent influential papers on SRI funds. Bauer et al. [35] was the document with the greatest connection strength (924 total link strength) and it had a high link with Statman [36], Renneboog et al. [2,37].

The blue cluster was formed by 13 documents and contained the influential papers that explained the mutual funds' performance. Most of the studies used Jensen's alpha [62], the Sharpe ratio [63] or the Treynor ratio [64] as performance measures. Other studies used time-series regressions based on the multifactor asset pricing model defined by Fama and French [65]. This model was extended by Carhart [66], adding a fourth factor, the momentum. To measure the conditional performance the approach of Ferson and Schadt [67] was applied too. So, this cluster represented the main models used in studies on SRI funds.

Finally, the yellow cluster was the smallest, with 10 papers, and contained influential papers about modern portfolio theory, such as Markowitz [68] or Sharpe [69], and portfolio selection of socially responsible investments $[34,44,70]$ 


\subsubsection{Author Co-Citation Analysis}

The second co-citation study analyzed the author co-citation network on socially responsible funds. White and Griffith [24] proposed that the author co-citation analysis could contribute to knowledge about the intellectual structure of scientific disciplines, understanding as "author" the set of papers published by an author.

There were a total of 4036 cited authors in the 209 documents analyzed, of which the 100 most cited are shown in Figure 4. Each node represented an author, and its size indicated the number of times the author had been referenced in the 209 documents. A link between two nodes indicated a co-citation relationship. Each link had a strength and the higher the strength, the greater the thickness of the link. The nodes were also grouped according to similarity.

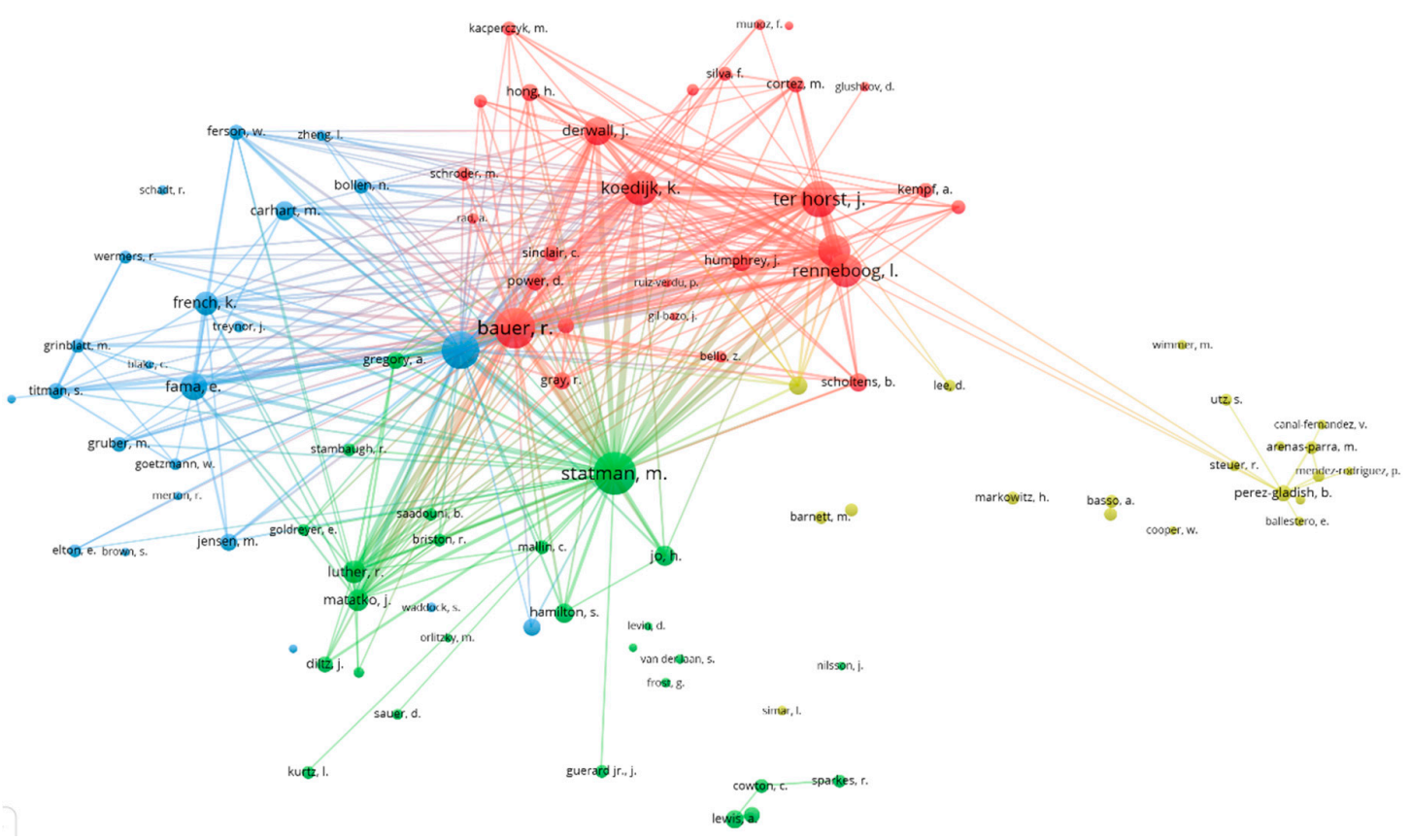

Figure 4. Co-citation network of authors of socially responsible funds

The nodes with the same color belong to the same cluster. The VOS Viewer software identified four groups.

The red cluster was the highest with 30 authors and the most important in terms of citations and total link strength, emphasizing mainly the group of authors formed by Bauer (171 citations and 7467 total link strength), Koedjik (137 citations and 5635 total link strength) and Derwall (99 citations and 4493 total link strength), and the other group of co-authors including Renneboog (131 citations and 5244 total link strength), Ter Horst (147 citations and 5964 total link strength) and Zhang (125 citations and 5082 total link strength). It is difficult to write a paper about SRI funds and not mention any paper of these authors because this cluster represents the current school of thought and includes the most recent influential authors in this research field. Moreover, it is important to note that Bauer is the central author on the map because he is one of the authors specialized in SRI issues, highlighting his paper published in 2005 entitled "The Eco-Efficiency Premium Puzzle" with 295 and 237 direct citations in Scopus and WOS, respectively. It should be noted that most of these economic studies have focused on the impact of risk and return on SRI funds, while Scholtens, the farthest author of this cluster, analyzes how social responsibility and financial performance of SRI funds are related. Recently, this author published the paper entitled "The sustainability of green funds" [71] and analyzed the development of a specific green policy instrument in the Netherlands and its relation to sustainable development. It is one of the first papers to provide information about the characteristics of the green projects promoted by green economies. 
The green cluster was comprised of 27 authors and contained those influential authors that evaluated the performance of ethical investments during the 1990 decade. The principal authors in this cluster were Statman (187 citations) and Luther and Matatko, co-authors, with 73 and 72 citations, respectively. Statman was the author with the most citations received and the second with the greatest connection strength (6894 total link strength). He had a high link strength with Bauer because Statman had an influential paper titled "Socially Responsible Mutual Funds", published in 2000, strongly related to Bauer's documents. In this cluster, it was also observed that there was a more distant group formed by Cowton, Lewis, Mackenzie and Sparkes, because they study the relationship between the ethical and financial beliefs and desires of an ethical investor. In general, they want to investigate how investors integrate their morality and beliefs into their economic decision process.

The third cluster (blue) was comprised of 23 authors and contained influential authors that explain the mutual funds' performance, such as Fama, French and Sharpe, but they do not analyze issues related to socially responsible funds. This cluster corresponded to the documents, which appeared in the blue cluster of Figure 3.

Finally, the yellow cluster was the smallest with twenty authors and showed less total link strength in comparison with the other three. This cluster was the farthest in the center of the map because it was the most different analyzed topic. It included authors such as Markowitz, Basso, Pérez-Gladish, among others and, their studies are based on the selection of socially responsible portfolios.

\subsubsection{Journal Co-Citation Analysis}

The third co-citation study analyzes the journal co-citation network on socially responsible funds. McCain [25] proposed the journal co-citation analysis to contribute to the study of the thematic organization of scientific disciplines. The frequency with which two sources are cited together denotes similarities between the journal scope and its research topics. In our sample of 209 documents, a total of 1200 cited sources were identified. Figure 5 shows the 50 most cited sources. Each node represented a source and the size of each node represented the number of citations received. A link between two items indicated a co-citation relationship. The nodes were grouped according to similarity; that is, the sources in the same cluster (color) and those that are closer together were more similar to each other.

Journal of Business Ethics had the most direct citations with 457 and a total link strength of 11,640 . It should be noted that the scope of this journal covers ethical issues related to business and finance, so this result is to be expected. Journal of Finance, however, had the greatest link strength with other papers $(14,672)$ because classic papers about portfolio theory and mutual fund performance are published in this journal [62,66-69]. Their citation is practically mandatory if researchers want to include in their analysis the performance as a variable. These papers, however, are not related to sustainability. Journal of Business (281 citations and 9925 total link strength), Journal of Banking and Finance (267 citations and 8527 total link strength) and Financial Analysts Journal (229 citations and 6508 total link strength) were the following most cited journals.

The most common fields publishing topics related to socially responsible funds were "Business and Finance" in WOS and "Economics, Econometrics and Finance" in Scopus.

The software VOS Viewer classified the journals into three clusters. The red cluster was comprised of 21 sources and included journals that are mainly related to the ethics of business, corporate social responsibility, and corporate sustainability (Journal of Business Ethics, Journal of Business Research, Business Ethics Quarterly, Business Ethics: A European Review, among others). The green cluster basically focused on relevant research in investment management, finance, and banking and it included 19 sources (Journal of Finance, Financial Analysis Journal, Journal of Banking and Finance, Journal of Corporate Finance, etc.). Finally, the blue cluster was the most different from the others thematically, since it mainly consisted of 10 journals that focus their research on operational research and decision making (European Journal of Operational Research, Fuzzy Sets and Systems, Omega, etc.). The last cluster published authors more distant thematically, as we have already seen in Figure 3. 


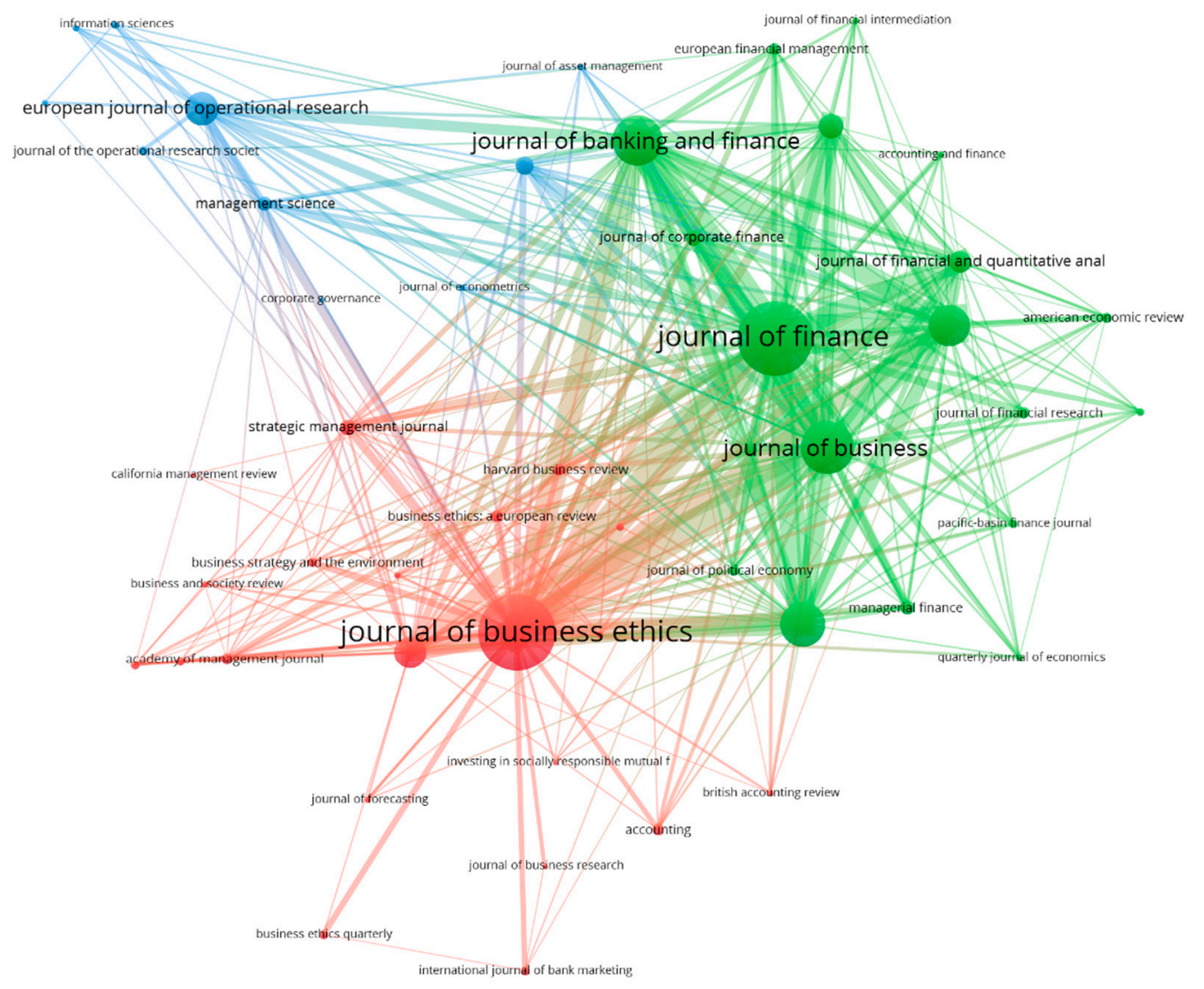

Figure 5. Co-citation network of sources of socially responsible funds

\section{Discussion and Conclusions}

This paper aims to add knowledge to the field of socially responsible funds. To do so, we carried out a bibliometric study using the VOS Viewer software and by applying two methods: A citation analysis and co-citation analysis. A total of 209 research papers found in two databases, WoS and Scopus, were analyzed.

The co-citation network of authors showed that the most important authors in terms of citations and total link strength were the most influential authors in the research field (Bauer, Statman, Otten, Koedijk, Renneboog, Ter Horst and Zhang). Moreover, the data revealed that the classic authors of portfolio theory or models to measure the performance (for example, Carhart, Fama or French) were referenced in papers about socially responsible funds, even though they did not analyze issues related to sustainability.

The co-citation map of journals highlighted two important clusters, one of which included those papers related to sustainability and finance, and another that included documents that proposed different methodologies applicable to any type of fund. The most important journals in terms of citations and total link strength were the Journal of Business Ethics and Journal of Finance.

The co-citation network of documents showed that the most important papers were "The international evidence on ethical mutual fund performance and investment style" and "Socially Responsible Mutual Funds" written by Bauer et al. [35] and Statman [36], respectively. The clusters of the map showed a clear difference between those documents published in the 1990s and current papers.

If we consider the topic of the 209 documents, the most frequent topic $(26.8 \%)$ analyzed the differences between SRI funds and conventional funds. More specifically, many of them focused on whether the performance of SRI funds was worse than that of conventional funds [35,43,72,73], whereas others analyzed the effect of size, cash flows [55] or fund fees [43,57]. Other authors focused on analyzing sustainable market indexes [36]. In recent years, the concept of green funds, any investment 
strategy to promote the sustainable development, has begun to appear in the economic literature derived from the growth of international initiatives at developing environmental and social policies on sustainable finance issues. For this reason, nowadays, the comparison of financial performance is between green and conventional funds [74-76].

The second most analyzed topic was investor attributes $(9.1 \%)$, the first paper was published in 1991, the purpose of which was to define the personal characteristics (educational level, age, etc.) of people who invest in ethical investment [77]. Other studies have aimed to explain why investors choose to invest different proportions of their investment portfolio in SRI funds [78-80]. In general, the results indicated that both financial perceptions and social preferences are related to investing in SRI. Investors expect to earn lower returns on SRI funds than on conventional funds and pay higher fees in accordance with their social preferences.

The next most analyzed topics in the field of research were investment screening $(8.1 \%)$ and green finance (7.2\%). Regarding investment screening, the papers mainly focused on whether the financial performances of SRI were related to the features of the screening process $[34,42,81,82]$.

With respect to green finance, different topics are emerging but it is still an incipient topic and there is a lack of documents about that. Some papers offer an overview of the green funds (or similar) market by comparing their performance and risk $[83,84]$. Other studies focus on how green funds contribute to the development of economies $[71,85,86]$. Scholtens [71] remarks on the importance of study green projects, analyzing their environmental, financial and social impact on a sustainable economy. According to Adamo et al. [83], the growth of green finance urges the use of investments as green funds because these funds invest in environmental companies, whose activities are concentrated in water treatment, against pollution, in areas such as alternative energy and energy efficiency.

It should be noted that the European Commission will specify the standards for green bond issuances to provide investors with additional information by 2019. Therefore, future research should evaluate the effectiveness of the European Commission proposals, verifying the environmental impact of green bonds in accordance with the EU Green Bond Standard and how they help to scale up investments in green projects and activities

In short, this is the only way to guarantee a sustainable world.

The main limitations of this paper must be mentioned. First, a major limitation was the reduced sample of documents, which restricted the interpretation of our findings and did not allow the study of co-word analysis. Second, two specific databases, WOS and Scopus, were selected rather than other databases like Google Scholar, among others. Third, Scopus and WOS included papers without keywords, which may have reduced the number of results obtained. Finally, the interpretation of the maps and the classification based on topics was subjective.

Author Contributions: This article is a joint work of the four authors. L.F.-A., M.G.B.-M., A.T., and L.P. contributed to the research ideas, literature review and analysis and to writing the paper. All authors read and approved the final manuscript.

Funding: The APC was funded by Markets and Finance Research Group (2017 SGR 00144) from the Universitat Rovira i Virgili (URV).

Conflicts of Interest: The authors declare no conflict of interest.

\section{References}

1. Escrig-Olmedo, E.; Fernández-Izquierdo, M.Á.; Ferrero-Ferrero, I.; Rivera-Lirio, J.M.; Muñoz-Torres, M.J. Rating the raters: Evaluating how ESG rating agencies integrate sustainability principles. Sustainability 2019, 11, 915. [CrossRef]

2. Renneboog, L.; Ter Horst, J.; Zhang, C. Socially responsible investments: Institutional aspects, performance, and investor behavior. J. Bank. Financ. 2008, 32, 1723-1742. [CrossRef]

3. Van Eck, N.J.; Waltman, L. Software survey: VOSviewer, a computer program for bibliometric mapping. Scientometrics 2010, 84, 523-538. [CrossRef] 
4. Castillo-Vergara, M.; Alvarez-Marin, A.; Placencio-Hidalgo, D. A bibliometric analysis of creativity in the field of business economics. J. Bus. Res. 2018, 85, 1-9. [CrossRef]

5. Dzikowski, P. A bibliometric analysis of born global firms. J. Bus. Res. 2018, 85, 281-294. [CrossRef]

6. Garrigos-Simon, F.; Narangajavana-Kaosiri, Y.; Lengua-Lengua, I. Tourism and sustainability: A bibliometric and visualization analysis. Sustainability 2018, 10, 1976. [CrossRef]

7. Köseoglu, M.A.; Sehitoglu, Y.; Craft, J. Academic foundations of hospitality management research with an emerging country focus: A citation and co-citation analysis. Int. J. Hosp. Manag. 2015, 45, 130-144. [CrossRef]

8. Sainaghi, R.; Phillips, P.; Baggio, R.; Mauri, A. Cross-citation and authorship analysis of hotel performance studies. Int. J. Hosp. Manag. 2018, 73, 75-84. [CrossRef]

9. Olawumi, T.O.; Chan, D.W.M. A scientometric review of global research on sustainability and sustainable development. J. Clean. Prod. 2018, 183, 231-250. [CrossRef]

10. Corsini, F.; Laurenti, R.; Meinherz, F.; Appio, F.P.; Mora, L. The advent of practice theories in research on sustainable consumption: Past, current and future directions of the field. Sustainability 2019, 11, 341. [CrossRef]

11. Fahimnia, B.; Sarkis, J.; Davarzani, H. Green supply chain management: A review and bibliometric analysis. Int. J. Prod. Econ. 2015, 162, 101-114. [CrossRef]

12. Feng, Y.; Zhu, Q.; Lai, K.H. Corporate social responsibility for supply chain management: A literature review and bibliometric analysis. J. Clean. Prod. 2017, 158, 296-307. [CrossRef]

13. Leung, X.Y.; Sun, J.; Bai, B. Bibliometrics of social media research: A co-citation and co-word analysis. Int. J. Hosp. Manag. 2017, 66, 35-45. [CrossRef]

14. Goyal, N. A "review" of policy sciences: Bibliometric analysis of authors, references, and topics during 1970-2017. Policy Sci. 2017, 50, 527-537. [CrossRef]

15. Merigó, J.M.; Mas-Tur, A.; Roig-Tierno, N.; Ribeiro-Soriano, D. A bibliometric overview of the journal of business research between 1973 and 2014. J. Bus. Res. 2015, 68, 2645-2653. [CrossRef]

16. Appio, F.P.; Martini, A.; Massa, S.; Testa, S. Unveiling the intellectual origins of social Media-based innovation: Insights from a bibliometric approach. Scientometrics 2016, 108, 355-388. [CrossRef]

17. Corsini, F.; Certomà, C.; Dyer, M.; Frey, M. Participatory energy: Research, imaginaries and practices on people' contribute to energy systems in the smart city. Technol. Forecast. Soc. Chang. 2018, 142, 322-332. [CrossRef]

18. Benckendorff, P.; Zehrer, A. A network analysis of tourism research. Ann. Tour. Res. 2013, 43, 121-149. [CrossRef]

19. Koseoglu, M.A.; Rahimi, R.; Okumus, F.; Liu, J. Bibliometric studies in tourism. Ann. Tour. Res. 2016, 61, 180-198. [CrossRef]

20. Hall, C.M. Publish and perish? Bibliometric analysis, journal ranking and the assessment of research quality in tourism. Tour. Manag. 2011, 32, 16-27. [CrossRef]

21. Hirsch, J.E. An index to quantify an individual's scientific research output. In Proceedings of the National Academy of Sciences, Stuttgart, Germany, 1 September 2005; Volume 102, pp. 16569-16572.

22. Zupic, I.; Čater, T. Bibliometric methods in management and organization. Organ. Res. Methods 2015, 18, 429-472. [CrossRef]

23. Small, H. Co-citation in the scientific literature: A new measure of the relationship between two documents. J. Am. Soc. Inf. Sci. 1973, 24, 265-269. [CrossRef]

24. White, H.D.; Griffith, B.C. Author cocitation: A literature measure of intellectual structure. J. Am. Soc. Inf. Sci. 1981, 32, 163-171. [CrossRef]

25. McCain, K.W. Mapping authors in intellectual space: A technical overview. J. Am. Soc. Inf. Sci. 1990, 41, 433-443. [CrossRef]

26. Ferreira, F.A.F. Mapping the field of arts-based management: Bibliographic coupling and co-citation analyses. J. Bus. Res. 2018, 85, 348-357. [CrossRef]

27. Andrade-Valbuena, N.A.; Merigo, J.M. Outlining new product development research through bibliometrics: Analyzing journals, articles and researchers. J. Strategy Manag. 2018, 11, 328-350. [CrossRef]

28. Acedo, F.J.; Barroso, C.; Casanueva, C.; Galán, J.L. Co-authorship in management and organizational studies: An empirical and network analysis. J. Manag. Stud. 2006, 43, 957-983. [CrossRef] 
29. Liao, H.; Tang, M.; Luo, L.; Li, C.; Chiclana, F.; Zeng, X.-J. A bibliometric analysis and visualization of medical big data research. Sustainability 2018, 10, 166. [CrossRef]

30. Callon, M.; Courtial, J.-P.; Turner, W.A.; Bauin, S. From translation to problematic networks: An introduction to co-word analysis. Soc. Sci. Inf. 1983, 22, 191-235. [CrossRef]

31. Benavides-Velasco, C.A.; Quintana-García, C.; Guzmán-Parra, V.F. Trends in family business research. Small Bus. Econ. 2013, 40, 41-57. [CrossRef]

32. Mora-Valentín, E.M.; Ortiz-de-Urbina-Criado, M.; Nájera-Sánchez, J.J. Mapping the conceptual structure of science and technology parks. J. Technol. Transf. 2018, 43, 1410-1435. [CrossRef]

33. Moher, D.; Liberati, A.; Tetzlaff, J.; Altman, D.G. Preferred reporting items for systematic reviews and meta-analyses: The PRISMA statement. Ann. Intern. Med. 2009, 151,1-8. [CrossRef]

34. Barnett, M.L.; Salomon, R.M. Beyond dichotomy: The curvilinear relationship between social responsibility and financial performance. Strateg. Manag. J. 2006, 27, 1101-1122. [CrossRef]

35. Bauer, R.; Koedijk, K.; Otten, R. International evidence on ethical mutual fund performance and investment style. J. Bank. Financ. 2005, 29, 1751-1767. [CrossRef]

36. Statman, M. Socially responsible mutual funds. Financ. Anal. J. 2000, 56, 30-39. [CrossRef]

37. Renneboog, L.; Ter Horst, J.; Zhang, C. The price of ethics and stakeholder governance: The performance of socially responsible mutual funds. J. Corp. Financ. 2008, 14, 302-332. [CrossRef]

38. Meyer, D.E.; Mehlman, D.W.; Reeves, E.S.; Origoni, R.B.; Evans, D.; Sellers, D.W. Comparison study of overlap among 21 scientific databases in searching pesticide information. Online Inf. Rev. 1983, 7, $33-43$. [CrossRef]

39. Rockness, J.W.; Williams, P.F. A descriptive study of social responsibility mutual funds. Account. Organ. Soc. 1988, 13, 397-411. [CrossRef]

40. Merigó, J.M.; Cancino, C.A.; Coronado, F.; Urbano, D. Academic research in innovation: A country analysis. Scientometrics 2016, 108, 559-593. [CrossRef]

41. Fowler, S.J.; Hope, C. A critical review of sustainable business indices and their impact. J. Bus. Ethics 2007, 76, 243-252. [CrossRef]

42. Capelle-Blancard, G.; Monjon, S. The performance of socially responsible funds: Does the screening process matter? Eur. Financ. Manag. 2014, 20, 494-520. [CrossRef]

43. Kreander, N.; Gray, R.H.; Power, D.M.; Sinclair, C.D. Evaluating the performance of ethical and non-ethical funds: A matched pair analysis. J. Bus. Financ. Account. 2005, 32, 1465-1493. [CrossRef]

44. Bello, Z.Y. Socially responsible investing and portfolio diversification. J. Financ. Res. 2005, 28, 41-57. [CrossRef]

45. Bauer, R.; Derwall, J.; Otten, R. The ethical mutual fund performance debate: New evidence from Canada. J. Bus. Ethics 2007, 70, 111-124. [CrossRef]

46. Cortez, M.C.; Silva, F.; Areal, N. The performance of European socially responsible funds. J. Bus. Ethics 2009, 87, 573-588. [CrossRef]

47. Abdelsalam, O.; Fethi, M.D.; Matallín, J.C.; Tortosa-Ausina, E. On the comparative performance of socially responsible and Islamic mutual funds. J. Econ. Behav. Organ. 2014, 103, S108-S128. [CrossRef]

48. Nofsinger, J.; Varma, A. Socially responsible funds and market crises. J. Bank. Financ. 2014, 48, $180-193$. [CrossRef]

49. Renneboog, L.; Ter Horst, J.; Zhang, C. Is ethical money financially smart? Nonfinancial attributes and money flows of socially responsible investment funds. J. Financ. Intermediat. 2011, 20, 562-588. [CrossRef]

50. Hong, H.; Kostovetsky, L. Red and blue investing: Values and finance. J. Financ. Econ. 2012, 103, 1-19. [CrossRef]

51. Utz, S.; Wimmer, M.; Hirschberger, M.; Steuer, R.E. Tri-criterion inverse portfolio optimization with application to socially responsible mutual funds. Eur. J. Oper. Res. 2014, 234, 491-498. [CrossRef]

52. Ballestero, E.; Bravo, M.; Pérez-Gladish, B.; Arenas-Parra, M.; Plà-Santamaria, D. Socially responsible investment: A multicriteria approach to portfolio selection combining ethical and financial objectives. Eur. J. Oper. Res. 2012, 216, 487-494. [CrossRef]

53. Bilbao-Terol, A.; Arenas-Parra, M.; Cañal-Fernández, V. Selection of socially responsible portfolios using goal programming and fuzzy technology. Inf. Sci. 2012, 189, 110-125. [CrossRef]

54. Bilbao-Terol, A.; Arenas-Parra, M.; Cañal-Fernández, V.; Antomil-Ibias, J. Using TOPSIS for assessing the sustainability of government bond funds. Omega 2014, 49, 1-17. [CrossRef] 
55. Bollen, N. Mutual fund attributes and investor behavior. J. Financ. Quant. Anal. 2007, 42, 683-708. [CrossRef]

56. Hamilton, S.; Jo, H.; Statman, M. Doing well while doing good? The investment performance of socially responsible mutual funds. Financ. Anal. J. 1993, 49, 62-66. [CrossRef]

57. Sauer, D.A. The impact of social-responsibility screens on investment performance: Evidence from the domini 400 social index and domini equity mutual fund. Rev. Financ. Econ. 1997, 6, 137-149. [CrossRef]

58. Goldreyer, E.; Diltz, J. The performance of socially responsible mutual funds: Incorporating sociopolitical information in portfolio selection. Manag. Financ. 1999, 25, 23-36. [CrossRef]

59. Luther, R.; Matatko, J.; Corner, D. The investment performance of UK ethical unit trusts. Account. Audit. Account. J. 1992, 5. [CrossRef]

60. Mallin, C.; Saadouni, B.; Briston, R. The financial performance of ethical investment funds. J. Bus. Financ. Account. 1995, 22, 483-496. [CrossRef]

61. Gregory, A.; Matatko, J.; Luther, R. Ethical unit trust financial performance: Small company effects and fund size effects. J. Bus. Financ. Account. 1997, 24, 705-725. [CrossRef]

62. Jensen, M. The performance of mutual funds in the period 1945-1964. J. Financ. 1968, 23, 389-416. [CrossRef]

63. Sharpe, W.F. Mutual fund performance. J. Bus. 1966, 39, 119-138. [CrossRef]

64. Treynor, J.; Mazuy, K. Can mutual funds outguess the market? Harv. Bus. Rev. 1966, 44, 131-136.

65. Fama, E.F.; French, K.R. Common risk factors in the returns on stocks and bonds. J. Financ. Econ. 1993, 33, 3-56. [CrossRef]

66. Carhart, M.M. On persistence in mutual fund performance. J. Financ. 1997, 52, 57-82. [CrossRef]

67. Ferson, W.; Schadt, R. Measuring fund strategy and performance in changing economic conditions. J. Financ. 1996, 41, 425-461. [CrossRef]

68. Markowitz, H. Portfolio selection. J. Financ. 1952, 7, 77-91.

69. Sharpe, W.F. Capital asset prices: A theory of market equilibrium under conditions of risk. J. Financ. 1964, 19, 425-442.

70. Hallerbach, W.; Ning, H.; Soppe, A.; Spronk, J. A framework for managing a portfolio of socially responsible investments. Eur. J. Oper. Res. 2004, 153, 517-529. [CrossRef]

71. Scholtens, B. The sustainability of green funds. Nat. Resour. Forum 2011, 35, 223-232. [CrossRef]

72. Bauer, R.; Otten, R.; Rad, A.T. Ethical investing in Australia: Is there a financial penalty? Pac. Basin Financ. J. 2006, 14, 33-48. [CrossRef]

73. Gil-Bazo, J.; Ruiz-Verdú, P.; Santos, A.A.P. The performance of socially responsible mutual funds: The role of fees and management companies. J. Bus. Ethics 2010, 94, 243-263. [CrossRef]

74. Chang, C.E.; Nelson, W.A.; Witte, H.D. Do green mutual funds perform well? Manag. Res. Rev. 2012, 35, 693-708. [CrossRef]

75. Silva, F.; Cortez, M.C. The performance of US and European green funds in different market conditions. J. Clean. Prod. 2016, 135, 558-566. [CrossRef]

76. Ibikunle, G.; Steffen, T. European green mutual fund performance: A comparative analysis with their conventional and black peers. J. Bus. Ethics 2017, 145, 337-355. [CrossRef]

77. Rosen, B.N.; Sandler, D.M.; Shani, D. Social issues and socially responsible investment behavior: A preliminary empirical investigation. J. Consum. Aff. 1991, 25, 221-234. [CrossRef]

78. Nilsson, J. Investment with a conscience: Examining the impact of pro-social attitudes and perceived financial performance on socially responsible investment behavior. J. Bus. Ethics 2008, 83, 307-325. [CrossRef]

79. Nilsson, J. Segmenting socially responsible mutual fund investors. Int. J. Bank Mark. 2009, $27,5-31$. [CrossRef]

80. Bauer, R.; Smeets, P. Social identification and investment decisions. J. Econ. Behav. Organ. 2015, 117, 121-134. [CrossRef]

81. Schwartz, M.S. The 'ethics' of ethical investing. J. Bus. Ethics 2003, 43, 195-213. [CrossRef]

82. Lee, D.D.; Humphrey, J.E.; Benson, K.L.; Ahn, J.Y.K. Socially responsible investment fund performance: The impact of social screens and intensity. Account. Financ. 2010, 50, 351-370. [CrossRef]

83. Adamo, R.; Federico, D.; Notte, A. Performance and risk of green funds. Invest. Manag. Financ. Innov. 2014, 11, 134-145.

84. Alvarez, M.; Rodriguez, J. Water-related mutual funds: Investment performance and social role. Soc. Responsib. J. 2015, 11, 502-512. [CrossRef] 
85. Stiglitz, J. Overcoming the Copenhagen failure with flexible commitments. Econ. Energy Environ. Policy 2015, 4, 29-36. [CrossRef]

86. Aglietta, M.; Hourcade, J.C.; Jaeger, C.; Fabert, B.P. Financing transition in an adverse context: Climate finance beyond carbon finance. Int. Environ. Agreem. Politics Law Econ. 2015, 15, 403-420. [CrossRef] 